\title{
Penerapan Supervisi Klinis untuk Meningkatkan Komitmen Kerja Guru
}

\author{
Gusti Ayu Kusumawati* \\ UPT Kecamatan Blahbatuh Gianyar
}

\begin{abstract}
Abstrak
Tujuan penelitian ini adalah untuk mengetahui peningkatan komitmen kerja guru SD di Gugus 3 Kecamatan Blahbatuh Kabupaten Gianyar Semester II Tahun Pelajaran 2018/2019 setelah mengikuti kegiatan supervisi klinis. Penelitian ini

Kata Kunci:

komitmen kerja guru, supervisi klinis. Kecamatan Blahbatuh Kabupaten Gianyar yang berjumlah 58 orang guru. Data komitmen kerja guru pada penelitian ini dikumpulkan menggunakan kuesioner. Teknik analisis data menggunakan analisis deskriptif. Indikator keberhasilan penelitian ini adalah: apabila rata-rata komitmen kerja guru minimal pada kategori Tinggi, dan ketuntasan klasikal sebesar 90\%. Berdasarkan penelitian yang telah dilakukan, disimpulkan bahwa penerapan supervisi klinis secara efektif dapat meningkatkan komitmen kerja guru SD di Gugus 3 Kecamatan Blahbatuh Kabupaten Gianyar Semester II Tahun Pelajaran 2018/2019. Pada pra siklus rerata komitmen kerja guru adalah 128,74 berada pada kategori sedang dengan persentase ketuntasan klasikalnya adalah 67,24\%. Pada siklus I rerata komitmen kerja guru adalah 145,98 berada pada kategori tinggi dengan persentase ketuntasan klasikalnya adalah 87,93\%. Sedangkan pada siklus II meningkat dengan rerata sebesar 180,45 berada pada kategori sangat tinggi dengan persentase ketuntasan klasikalnya adalah $100 \%$.
\end{abstract}

\begin{abstract}
The purpose of this study was to determine the increase in elementary school teacher work commitments in Cluster 3 Blahbatuh District, Gianyar Regency Semester II in the 2018/2019 Academic Year after attending clinical supervision activities. This

Keywords:

teacher work commitment, clinical supervision. research is a school action research. Subjects were elementary school teachers in Cluster 3, Blahbatuh District, Gianyar Regency with a total of 58 teachers. Teacher work commitment data in this study were collected using a questionnaire. Data analysis techniques using descriptive analysis. Indicators of the success of this study are: if the minimum teacher work commitment is in the High category, and classical completeness is $90 \%$. Based on the research that has been done, it was concluded that the effective implementation of clinical supervision could increase the work commitments of elementary school teachers in Cluster 3 of Blahbatuh District, Gianyar Regency Semester II in 2018/2019 Academic Year. In the pre-cycle mean teacher work commitment is 128.74 in the medium category with the percentage of classical completeness is $67.24 \%$. In the first cycle the mean work commitment of teachers was 145.98 in the high category with the percentage of classical completeness being $87.93 \%$. Whereas in cycle II it increased with a mean of 180.45 in the very high category with the percentage of classical completeness being $100 \%$.
\end{abstract}

\footnotetext{
* Corresponding author.

E-mail Addresses: - ayugusti1964@gmail.com (Gusti Ayu Kusumawati)
} 


\section{PENDAHULUAN}

Pendidikan merupakan aspek yang paling penting yang tidak bisa lepas dari kehidupan manusia. Setiap Manusia dalam kehidupannya akan selalu berkaitan dengan penidikan. Pendidikan merupakan suatu usaha sadar dan terencana untuk memanusiakan manusia kearah yang lebih baik. Salah satu indikator yang menentukan derajat manusia dapat dilihat dari pendidikannya. Semakin tinggi tingkat pendidikan seseorang, semakin tinggi juga derajat seseorang di lingkungan masyarakat.

Undang-undang Sisdiknas No. 20 Tahun 2003, yang menyatakan bahwa pendidikan adalah usaha sadar dan terencana untuk mewujudkan suasana belajar dan proses pembelajaran agar peserta didik secara aktif mengembangkan potensi dirinya untuk memiliki kekuatan spiritual keagamaan, pengendalian diri, kepribadian, kecerdasan, akhlak mulia, serta keterampilan yang diperlukan dirinya, masyarakat, bangsa dan Negara.

Berdasarkan pernyataan UU No. 20 tahun 2003 tentang SISDIKNAS dapat diketahui bahwa tujuan pendidikan adalah mewujudkan suasana belajar dan proses pembelajaran agar peserta didik aktif mengembangkan potensi dirinya. Untuk mencapai tujuan tersebut, penyelenggaraan pendidikan di Indonesia dilaksanakan dengan mengacu pada kurikulum.

Dalam pendidikan tidak terlepas dari adanya peran guru. Guru memegang peranan yang sangat strategis terutama dalam membentuk watak bangasa serta mengembangkan potensi siswa. Guru memiliki peranan yang sangat penting dalam menentukan keberhasilan pendidikan. Guru yang profesional diharapkan menghasilkan lulusan yang berkualitas. Profesionalisme guru sebagai ujung tombak di dalam implementasi kurikulum di kelas yang perlu mendapat perhatian. (Depdiknas,2005). Dalam proses belajar mengajar, guru mempunyai tugas untuk mendorong, membimbing, dan memberi fasilitas belajar bagi siswa untuk mencapai tujuan. Penyampaian materi pelajaran hanyalah merupakan salah satu dari kegiatan dalam belajar sebagai suatu proses yang dinamis dalam segala fase dan proses perkembangan siswa.

Peningkatan efektifitas di sekolah sangat ditentukan oleh kinerja pengawas. Pengawas yang berkinerja baik diperlihatkan dalam kemampuan manajemen pengawas yang mampu: (a) menjabarkan sumber daya yang ada untuk menyediakan dukungan yang memadai bagi guru, bahan pengajaran dan pemeliharaan fasilitas yang baik; (b) memberikan waktu yang cukup untuk pengelolaan dan koordinasi proses intruksional; (c) berkomunikasi secara teratur dengan staf, orang tua, siswa dan masyarakat terkait. Dengan kata lain, bahwa efektivitas sekolah ditentukan oleh kepemimpinan manajerial pengawas.

Dalam dunia pendidikan komitmen dan profesionalisme guru sangat dituntut karena mengajar sebagai inti dari proses pendidikan. Sebagai sebuah profesi pekerjaan sebagai guru tidak hanya menuntut kemampuan intelaktual dan fisik, tetapi juga menuntut kemampuan psikologis dan efektif. Komitmen memiliki peranan penting terutama pada kinerja seseorang ketika bekerja,hal ini disebabkan oleh adanya komitmen yang menjadi acuan serta dorongan yang membuat mereka lebih bertanggung jawab terhadap kewajibannya. Namun kenyataanya banyak organisasi atau perusahaan yang kurang memperhatikan mengenai komitmen/loyalitas karyawannya sehingga kinerja mereka kurang maksimal.

Realita yang terjadi di Gugus 3 Kecamatan Blahbatuh Kabupaten Gianyar Semester II Tahun Pelajaran 2018/2019, terlihat bahwa komitmen kerja guru masih cenderung rendah. Hal ini tercermin dari jarangnya guru menggunakan pembelajaran yang inovatif dalam pembelajaran, beberapa guru pengadministrasiannya masih cenderung rendah, dan ada beberapa guru yang malu-malu dalam menyampaikan kendala yang dihadapinya dalam menjalankan tugas. Dampak dari permasalahan ini membuat proses pendidikan di Gugus 3 Kecamatan Blahbatuh Kabupaten Gianyar Semester II Tahun Pelajaran 2018/2019 kurang optimal.

Untuk mengatasi permasalahan di atas, dapat diterapkan supervisi klinis. Pada hakekatnya supervisi sangat diperlukan oleh para guru, karena mereka menginginkan keberhasilan pelaksanaan fungsi dan tugas mengajarnya. Beberapa alasan pentingnya supervisi klinis dilakukan menurut Ma'mur (2012:105) yaitu sebagai berikut. 1) tidak ada umpan balik dari orang yang kompeten sehubungan dengan praktik profesional untuk memenuhi stándar kompetensi dan kode etik, 2) ketinggalan IPTEK dalam proses pembelajaran,3) kehilangan identitas profesi, 4) kejenuhan profesional, 5) pelanggaran kode etik yang akut, 6) mengulang kekeliruan secara masif, 7) Erosi pengetahuan yang sudah didapat dari pendidikan prajabatan (PT), 8) Siswa dirugikan, tidak mendapat layanan sebagaimana mestinya, dan 9) rendahnya apresiasi dan kepercayaan masyarakat dan pemberi kepercayaan.

Berdasarkan pemaparan di atas, maka pada penelitian ini mengambil judul tentang Penerapan Supervisi Klinis untuk Meningkatkan Komitmen Kerja Guru SD di Gugus 3 Kecamatan Blahbatuh Kabupaten Gianyar Semester II Tahun Pelajaran 2018/2019 


\section{METODE PENELITIAN}

Penelitian ini dilaksanakan SD di Gugus 3 Kecamatan Blahbatuh Kabupaten Gianyar Semester II Tahun Pelajaran 2018/2019. Dalam penelitian ini yang menjadi subjek penelitian adalah guru SD di Gugus 3 Kecamatan Blahbatuh Kabupaten Gianyar Semester II Tahun Pelajaran 2018/2019 sebanyak 58 orang guru. Sedangkan objek dari penelitian ini adalah Komitmen Kerja Guru dengan mengikuti supervisi klinis.

Jenis penelitian ini adalah penelitian tindakan sekolah (PTS). Penelitian tindakan sekolah merupakan suatu penelitian yang bertujuan untuk memperbaiki kegiatan-kegiatan yang dilaksanakan di sekolah, sehingga kualitas sekolah dapat ditingkatkan.

Penelitian tindakan sekolah (PTS) ini ada empat tahapan pada satu siklus penelitian. Keempat tahapan tersebut terdiri dari: planing, action, observation/evaluation, dan reflection. Pelaksanaan penelitian ini dilakukan beberapa siklus, dan setiap siklus tersebut dapat digambarkan dalam model seperti gambar sebagai berikut.

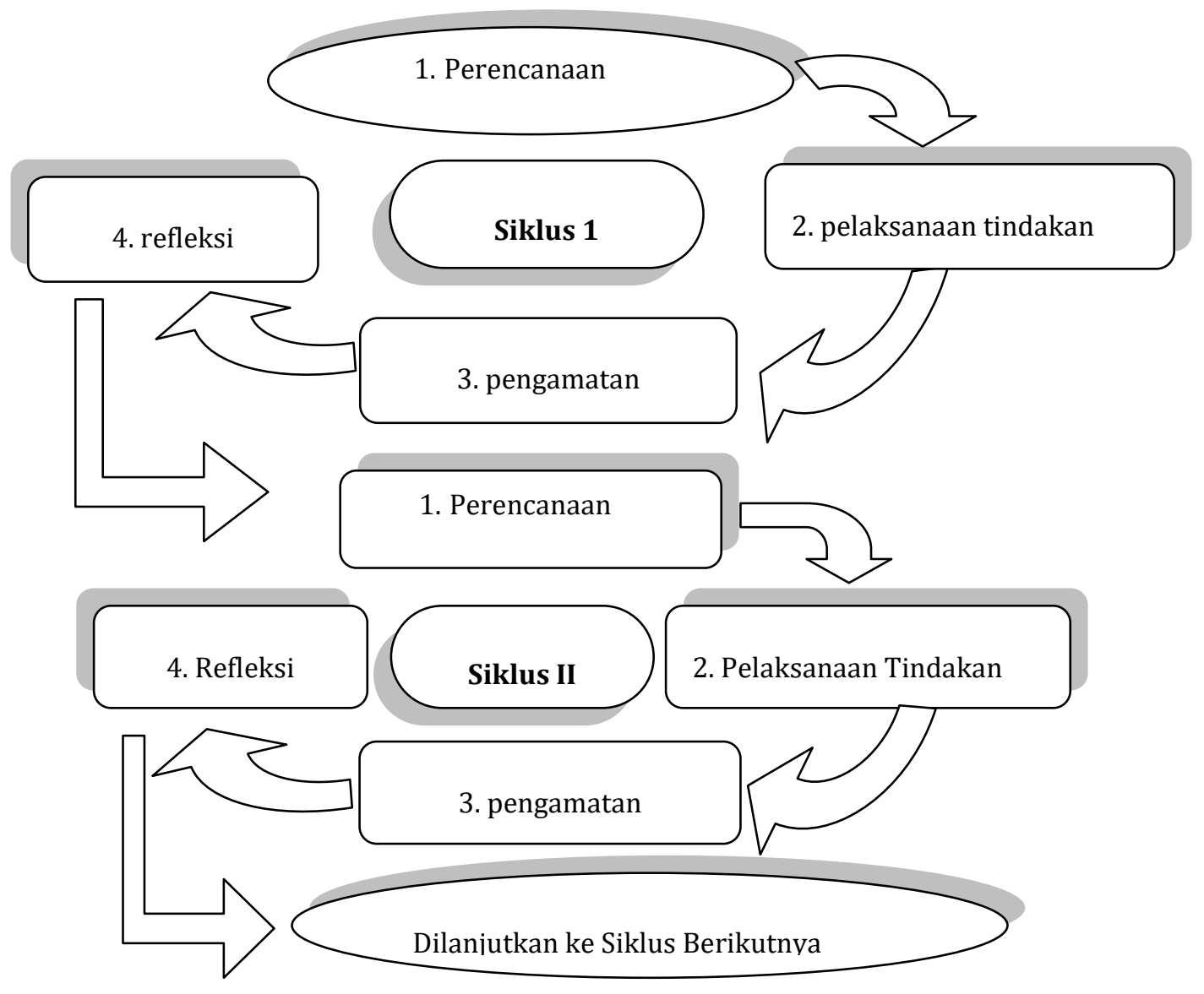

(Sumber: Arikunto, 2006:16)

Gambar 3.1 Model Penelitian Tindakan Sekolah Dua Siklus

Berdasarkan rancangan model Model Penelitian tindakan sekolah Dua Siklus di atas, dapat dijabarkan sebagai berikut.

\section{Rancangan Penelitian tindakan sekolah Siklus I}

Siklus I dilakukan dalam tiga kali pertemuan. Siklus tersebut mengacu pada empat tahap pelaksanaan PTS. Keempat tahapan tersebut terdiri dari: rencana tindakan, observation/evaluation, dan refleksi.

\section{a. Rencana tindakan}

Agar pelaksanaan pembelajaran dapat diterapkan dengan baik dan sesuai dengan tujuan penelitian yang dirumuskan, ada beberapa hal yang perlu dipersiapkan oleh peneliti, yaitu sebagai berikut.

a. Mengkaji sekolah yang akan diberikan tindakan

b. Menyiapkan materi yang berkaitan dengan supervisi klinis 
c. Menyiapkan instrument untuk mengumpulkan data yang diperlukan seperti kuesioner yang digunakan untuk mengetahui Komitmen Kerja Guru.

\section{b. Pelaksanaan tindakan}

Pada siklus I ini, tindakan dilakukan tiga (3) x pertemuan sesuai dengan perencanaan yang telah dibuat sebelumnya, dimana masing-masing pertemuan diatur sesuai perencanaan yang telah dirancang peneliti.

\section{c. Pemantauan/observasi dan Evaluasi}

Pemantauan/observasi dilakukan pada saat pelaksanaan tindakan yang meliputi hal-hal yang berkaitan pelaksanaan tindakan menggunakan lembar pengamatan/observasi.

\section{d. Refleksi}

Refleksi diberikan untuk melihat sejauh mana Komitmen Kerja Guru pada siklus I. Berdasarkan hasil refleksi ini digunakan sebagai dasar untuk memperbaiki dan menyempurnakan perencanaan dan pelaksanaan tindakan pada siklus I serta mencari cara untuk memecahkan masalah yang ada, yang selanjutnya akan dirumuskan untuk pelaksanaan siklus selanjutnya.

\section{Rancangan Penelitian tindakan sekolah Siklus II}

Pada siklus II, dilaksanakan dengan memperhatikan hasil evaluasi pada siklus I dengan memperbaiki tindakan sesuai hasil refleksi siklus I. Tahap penelitian siklus II juga sama seperti siklus I.

Dalam penelitian ini digunakan metode pengumpulan data yaitu metode kuesioner. Metode kuesioner digunakan untuk mengumpulkan data tentang Komitmen Kerja Guru. Kuesioner yang dibuat menggunakan skala likert 1-5, sehingga data yang diperoleh berupa skor.

Setelah data dalam penelitian ini terkumpul selanjutnya dilakukan analisis data deskriptif. Dalam penerapan metode analisis statistik deskriptif ini, data yang diperoleh dari hasil penelitian dianalisis dan disajikan ke dalam: a) menghitung angka rata-rata (Mean), b) menghitung median, c) menghitung modus. Mean, median modus dihitung dengan bantuan Microsoft excel.

Indikator keberhasilan penelitian ini, berpedoman pada kriteria berikut. Tingkat keberhasilan dalam penelitian ini adalah apabila rata-rata Komitmen Kerja Guru minimal pada kategori Tinggi, dan ketuntasan klasikal sebesar $90 \%$.

\section{ANALISIS DAN PEMBAHASAN}

Berdasarkan analisis data komitmen kerja guru sebelum dilakukan penelitian didapatkan rata-rata komitmen kerja guru sebesar 128,74 yang berada pada kategori sedang, dengan ketuntasan klasikal sebesar $67,24 \%$. Hal ini terlihat bahwa perlu adanya perbaikan upaya dalam meningkatkan komitmen kerja guru di gugus 3 Kecamatan Blahbatuh Kabupaten Gianyar Semester II Tahun Pelajaran 2018/2019.

Salah satu upaya yang sudah dilakukan adalah dengan menerapkan supervisi klinis. Supervisi klinis adalah supervisi yang memiliki ciri-ciri esensial sebagai berikut: (1) Bimbingan dari supervisor kepada guru bersifat bantuan, bukan perintah atau instruksi, sehingga prakarsa dan tanggung jawab pengembangan diri berada di tangan guru; (2) Hubungan interaksi dalam proses supervisi bersifat kolegial, sehingga intim dan terbuka; (3) Meskipun unjuk kerja mengajar guru di kelas bersifat luas dan terintegrasi, tetapi sasaran supervisi terbatas pada apa yang dikontrakkan; (4) Sasaran supervisi diajukan oleh guru, dikaji dan disepakati bersama dalam kontrak; (5) Proses supervisi klinis melalui tiga tahapan: pertemuan pendahuluan, observasi kelas, dan pertemuan balikan; (6) Instrumen observasi ditentukan bersama oleh guru dan supervisor; (7) Balikan yang objektif dan spesifik diberikan dengan segera; (8) Analisis dan interpretasi data observasi dilakukan bersama-sama; (9) Proses supervisi bersiklus.

Tujuan supervisi klinis dapat dibedakan menjadi: (1) Tujuan umum, dan (2) Tujuan khusus. Tujuan umum dari supervisi klinis adalah agar guru memiliki kemampuan untuk memperbaiki dirinya dalam melaksanakan proses pembelajaran. Sedangkan tujuan khusus supervisi klinis adalah sebagai berikut.

a. Guru memiliki keterampilan dalam mendiagnosis kesulitan pembelajaran dan mencari solusi pemecahannya.

b. Guru memiliki keterampilan dalam melaksanakan pembelajaran dengan menggunakan strategi yang efektif.

c. Guru memiliki sifat yang positif dan kritis terhadap upaya perbaikan mutu pembelajaran.

Berdasarkan penelitian yang telah dilakukan dengan menerapkan supervisi klinis didapatkan hasil pada siklus I rerata komitmen kerja guru adalah 145,98 dan berada pada kategori tinggi. Persentase ketuntasan klasikalnya adalah $87,93 \%$. Hal tersebut dikarenakan 7 orang guru mendapatkan skor yang berdada pada kategori sedang. Kendala yang dihadapi pada siklus I adalah guru belum optimal dalam menerapkan pembelajaran inovatif di kelas dan ada beberapa guru yang yang kurang terbuka mengenai permasalahan yang dihadapinya dalam menjalankan tugasnya di sekolah. 
Untuk lebih memaksimalkan hasil penelitian pada siklus I, maka diadakan penelitian siklus II dengan memperhatikan segala kendala yang terjadi pada siklus I. Pada siklus II komitmen kerja guru meningkat, hal tersebut terlihat dari rerata komitmen kerja guru adalah 180,45 dan berada pada kategori sangat tinggi. Persentase ketuntasan klasikalnya adalah 100\%. Hal ini menunjukkan bahwa kendalakendala yang dihadapi pada siklus I sudah dapat diatasi pada siklus II. Maka dari itu kriteria ketuntasan minimal baik dan ketuntasan klasikal 100\% sudah terpenuhi sehingga penelitian pada siklus II dinyatakan berhasil dan siklus dihentikan.

Peningkatan rata-rata dan ketuntasan klasikal pada hasil penelitian ini dapat digambarkan pada histogram berikut.

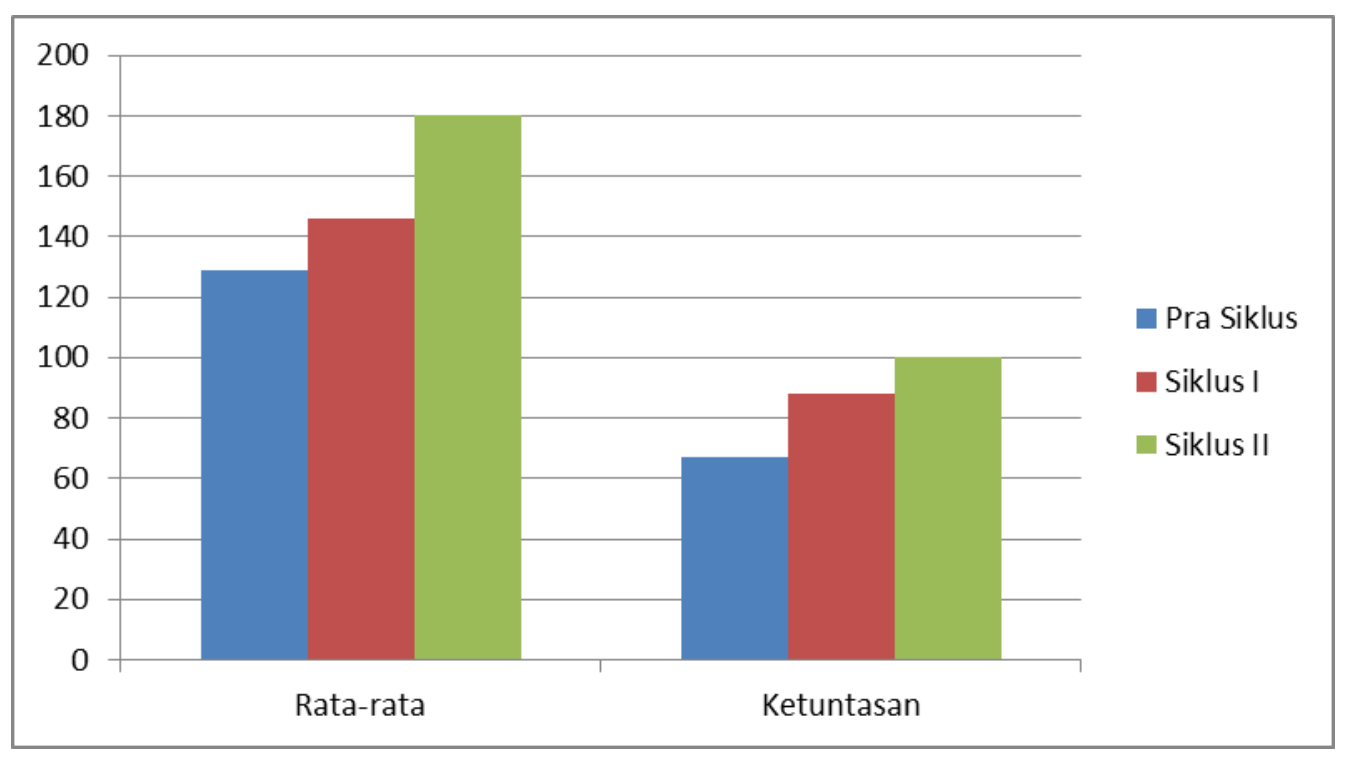

Gambar 2. Peningkatan Rata-Rata dan Ketuntasan Klasikal

Hasil penelitian ini sejalan dengan hasil penelitian yang dilakukan Karmanto (2017) dengan judul Supervisi Klinis: Peningkatan Kemampuan Guru dalam Mengajar di Wilayah MI Binaan Kecamatan Semin Gunungkidul Semester I Tahun 2016/2017. Dalam penelitiannya dinyatakan bahwa: Hasil tindakan yang meningkat pada siklus II, rata-rata kemampuan guru mengajar sesuai dengan standar proses terutama dalam penampilan mengajar sudah memenuhi kriteria keberhasilan yaitu baik. Pada siklus I terdapat 50\% atau setengah dari jumlah 6 guru belum memenuhi kriteria baik, 2 guru atau 33,33\% dengan kriteria baik serta 1 guru atau 16,67\% sangat baik. Atau nilai rata-rata siklus I 79,85 meningkat pada siklus II menjadi 84,30 atau naik menjadi 4,44\%. Setelah diberi tindakan pada siklus II kemampuan guru mengajar menjadi $100 \%$, satu diantaranya dengan kriteria sangat baik dengan nilai 94,22 atau 16,67\%.

Tanama, dkk (2016) dengan judul Implementasi Supervisi Klinis Dalam Meningkatkan Profesionalisme Guru. Hasil penelitian menunjukkan implementasi supervisi klinis yang dilaksanakan dalam tiga tahap yaitu tahap perencanaan, tahap pelaksanaan, dan tahap umpan balik telah berjalan dengan baik dan dapat meningkatkan profesionalisme guru. Berbagai upaya peningkatan dan pengembangan profesional guru telah diusahakan, seperti penguasaan materi, pemilihan metode pembelajaran, dan media yang digunakan. Sejalan dengan penelitian oleh Nuriati (2019) menyatakan bahwa Penerapan model pembelajaran Kooperatif Tipe Team Assissted Individualization (TAI) melalui supervisi klinis dapat meningkatkan kemampuan guru di SD Negeri 6 Batubulan dalam melaksanakan proses pembelajaran yang inovatif pada semester II tahun pelajaran 2017/2018. Begitupula penelitian oleh Suyasa (2019) yang menyatakan Melalui supervisi klinis dengan mengikuti alur pembelajaran inquiri dapat meningkatkan kemampuan guru di SD Negeri 2 Gianyar dalam melaksanakan proses pembelajaran yang efektif pada semester II tahun pelajaran 2017/2018.

\section{KESIMPULAN}

Berdasarkan penelitian yang telah dilakukan, dapat disimpulkan bahwa: penerapan supervisi klinis secara efektif dapat meningkatkan komitmen kerja guru SD di Gugus 3 Kecamatan Blahbatuh Kabupaten Gianyar Semester II Tahun Pelajaran 2018/2019. Pada pra siklus rerata komitmen kerja guru adalah 128,74 berada pada kategori sedang dengan persentase ketuntasan klasikalnya adalah 67,24\%. Pada 
siklus I rerata komitmen kerja guru adalah 145,98 berada pada kategori tinggi dengan persentase ketuntasan klasikalnya adalah $87,93 \%$. Sedangkan pada siklus II meningkat dengan rerata sebesar 180,45 berada pada kategori sangat tinggi dengan persentase ketuntasan klasikalnya adalah $100 \%$.

Saran yang dapat diajukan berdasarkan penelitian yang telah dilakukan adalah sebagai berikut.

1) Guru diharapkan selalu bersemangat dalam bekerja sehingga hasil pekerjaan yang dihasilkannya menjadi optimal.

2) Kepala sekolah diharapkan selalu memotivasi guru dalam melaksanakan tugasnya, sehingga komitmen guru menjadi meningkat dalam bekerja dan kinerja guru pun dapat ditingkatkan.

3) Peneliti lain hendaknya mengembangkan penelitian ini dengan menggunakan variabel-variabel yang lebih beragam, sehingga permasalahan dalam dunia pendidikan dapat diminimalkan..

\section{DAFTAR PUSTAKA}

Agung, A.A Gede. 2010. Metodologi Penelitian Pendidikan. Singaraja: Fakultas Ilmu Pendidikan Universitas Ganesha.

Arikunto, Suharsini. 2006. Dasar-dasar Supervisi Pendidikan. Jakarta: PT. Rieneka Cipta.

Bolla J.I. 1985. Supervisi Klinis. Direktorat Pendidikan Tinggi, Departemen Pendidikan dan Kebudayaan. Jakarta: P3TK.

Depdiknas. 2005. Pembinaan Profesionalisme Tenaga Pengajar (Pengembangan Profesionalisme Guru). Jakarta: Direktorat Jenderal Pendidikan Dasar dan Menengah Direktorat Pendidikan Lanjutan Pertama Depdiknas.

Hoy W.K, Forsyth P.B. 1986. Effective Supervision,Theory into Practice. New York: Random House, Inc.

Karmanto. 2017. Supervisi Klinis: Peningkatan Kemampuan Guru dalam Mengajar di Wilayah MI Binaan Kecamatan Semin Gunungkidul Semester I Tahun 2016/2017. Jurnal pendidikan Madrasah Volume 3 Nomor 2.

Ma'mur Asmani, Jamal. 2012. Tisp Efektif Supervisi Pendidikan Sekolah. Jogjakarta : DIVA Press.

Nuriati, Ni Wayan. 2019. Penerapan Model Pembelajaran Kooperatif Tipe Team Assissted Individualization (Tai) Melalui Supervisi Klinis Untuk Meningkatkan Kemampuan Guru Dalam Melaksanakan Proses Pembelajaran Yang Inovatif. Journal for Lesson and Learning Studies Vol. 2 No.2

Sahertian, P.A. 2000. Konsep Dasar dan Teknik Supervisi Pendidikan dalam Rangka Pengembangan Sumber Daya Manusia. Jakarta: Rineka Cipta.

Suyasa, I Made. 2019. Meningkatkan Kemampuan Guru dalam Melaksanakan Pembelajaran yang Efektif Melalui Pelaksanaan Supervisi Klinis dengan Mengikuti Alur Pembelajaran Inkuiri. Jurnal Pedagogi dan Pembelajaran Universitas Pendidikan Ganesha.

Tanama, Yulia Jayanti dkk. 2016. Implementasi Supervisi Klinis Dalam Meningkatkan Profesionalisme Guru. Jurnal Pendidikan Teori Penelitian dan Pengembangan Pascasarjana Universitas Negeri Malang Volume 1 Nomor 11.

Wahjosumidjo. 2013. Kepemimpinan Kepala Sekolah (Tinjauan Teoritik dan Permasalahannya). Jakarta: Raja Grafindo Persada. 